\title{
ANALISIS KOMODITAS UNGGULAN TANAMAN PANGAN DI KECAMATAN CIPATUJAH KABUPATEN TASIKMALAYA
}

\section{THE DETERMINATION OF LEADING FOOD CROPS ANALYSIS IN CIPATUJAH DISTRICT TASIKMALAYA REGENCY}

\author{
ASEP SUNJAYA*1 ${ }^{1}$, TRISNA INSAN NOOR ${ }^{2}$, AGUS YUNIAWAN ISYANTO ${ }^{1}$ \\ ${ }^{1}$ Fakultas Pertanian Universitas Galuh \\ ${ }^{2}$ Fakultas Pertanian Universitas Padjadjaran \\ *E-mail: asepsunjaya90@gmail.com
}

\begin{abstract}
ABSTRAK
Pemilihan komoditas unggulan yang sesuai dengan potensi wilayah dilakukan untuk menentukan komoditi tanaman pangan potensial yang dapat dikembangkan dan menjadi prioritas pengembangan. Penelitian ini bertujuan untuk menentukan komoditi unggulan tanaman pangan di Kecamatan Cipatujah Kabupaten Tasikmalaya berdasarkan keunggulan kompetitif dan komparatif dari luas panen dan nilai produksi. Penelitian dilakukan di Kecamatan Cipatujah pada bulan Juli 2020. Data yang dikumpulkan adalah data sekunder berupa data time series luas panen dan nilai produksi tanaman pangan padi sawah, padi gogo, jagung, ubi kayu, dan kacang tanah periode 20010-2019 yang diperoleh dari BPS Kabupaten Tasikmalaya. Komoditas yang memiliki keunggulan komparatif dianalisis dengan model Location Quotient (LQ), sedangkan komoditas yang memiliki keunggulan kompetitif dianalisis dengan model Shift Share Analysis (SSA). Hasil penelitian menunjukkan bahwa komoditas yang mempunyai keunggulan komparatif berdasarkan luas panen adalah yaitu padi sawah, padi gogo, jagung, ubi kayu, dan kacang tanah. Sedangkan komoditas yang mempunyai keunggulan komparatif berdasarkan nilai produksi adalah padi sawah, padi gogo, jagung, ubi kayu, dan kacang tanah. Komoditas tanaman pangan yang memiliki keunggulan kompetitif berdasarkan luas panen adalah padi sawah dan padi gogo. Sedangkan komoditas tanaman pangan yang memiliki keunggulan kompetitif berdasarkan nilai produksi adalah padi sawah, padi gogo, jagung dan ubi kayu. Komoditas tanaman pangan yang mempunyai keunggulan komparatif dan kompetitif adalah padi sawah, padi gogo, dan jagung.
\end{abstract}

Kata kunci: tanaman pangan, komoditas unggulan

\begin{abstract}
The selection of superior commodities in accordance with the potential of the region is done for determine potential food crop commodities that can be developed and become development priorities. This study aims to determine the leading commodity of food crops in Cipatujah District, Tasikmalaya Regency based on competitive and comparative advantages of harvested area and production value. The study was conducted in Cipatujah Subdistrict in July 2020. The data collected was secondary time series data on harvested area and the production value of food crops of lowland paddy, upland paddy, maize, cassava, and peanut in the period of 20010-2019 obtained from BPS-Statistic of Tasikmalaya Regency. Commodities that have a comparative advantage are analyzed by the Location Quotient $(L Q)$ model, while commodities that have a competitive advantage are analyzed by the Shift Share Analysis (SSA) model. The results showed commodities that had comparative advantages of harvested area is lowland paddy, upland paddy, maize, cassava, and peanuts. While food crops that have a comparative advantage with the production value are lowland paddy, upland paddy, maize, cassava, and peanuts. Food crops that have competitive advantages of
\end{abstract}


harvested area is lowland paddy and upland paddy. While food crops that have a competitive advantage with the production value are lowland paddy, upland paddy, maize, and cassava. Food crops that have comparative and competitive advantages is lowland paddy, upland paddy, and maize.

Keywords: food crop, leading commodities

\section{PENDAHULUAN}

Indikasi keberhasilan pertumbuhan ekonomi ditunjukkan dari pertambahan produksi atau pendapatan daerah yang berasal dari berbagai sektor. Kabupaten Tasikmalaya merupakan salah satu daerah di Jawa Barat yang mempunyai laju PDRB pada kisaran 5\%.

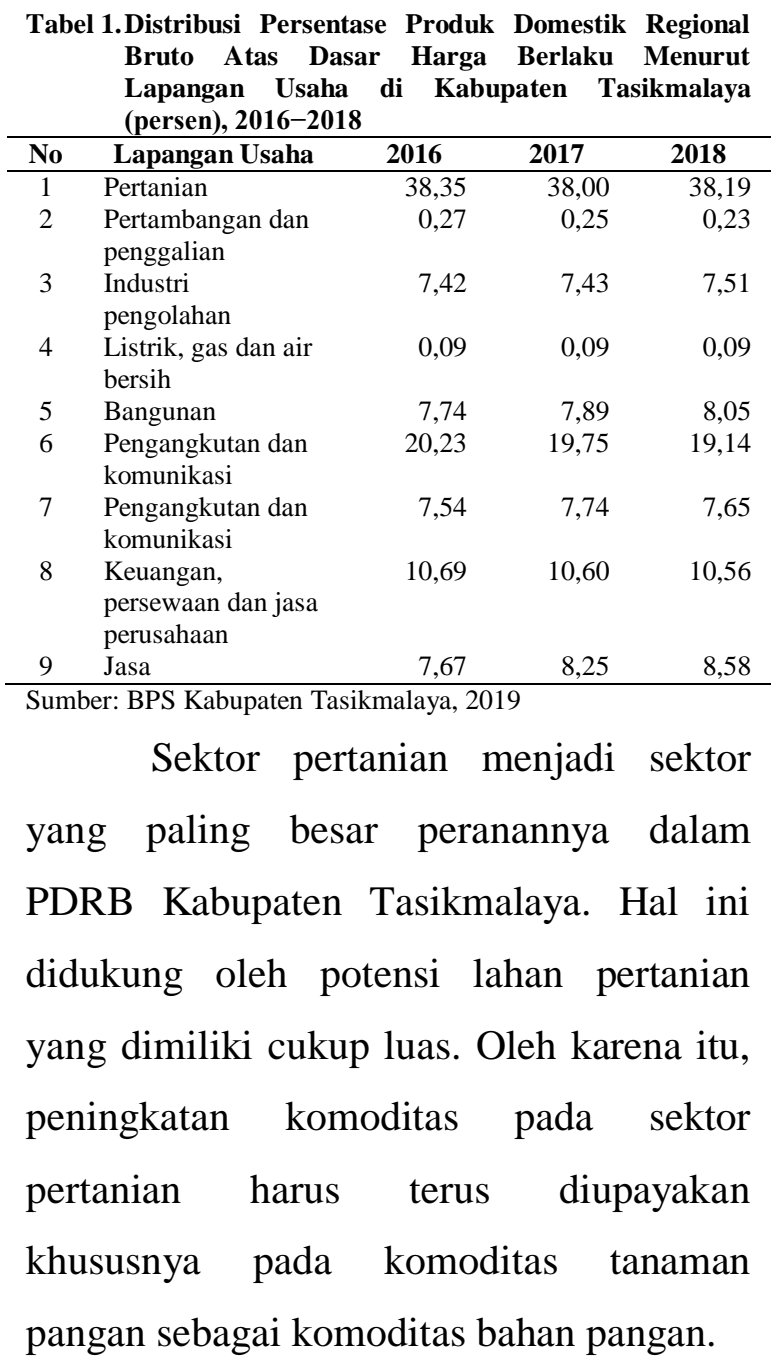

Kecamatan Cipatujah menjadi daerah dengan produksi tanaman pangan terbesar di Kabupaten Tasikmalaya. Dalam upaya pengembangan komoditi tanaman pangan khususnya di Kecamatan Cipatujah, maka komoditas tersebut harus memiliki keunggulan komparatif dan kompetitif yang mampu bersaing di pasar dibandingkan dengan daerah lainnya. Model analisis yang umum digunakan yaitu Location Quotient (LQ) dan Shift Share (SS)

LQ menghitung perbandingan share output sektor i di kota atau kabupaten, dan share out sektor i di provinsi. Sektor unggulan di sini berarti sektor bisnis yang tidak akan habis apabila dieksploitasi oleh pemerintah wilayah. Menurut Hood (1998) dalam Hendayana (2003), LQ adalah suatu alat pengembangan ekonomi yang lebih sederhana dengan segala kelebihan dan keterbatasannya. SS umumnya dipakai untuk menganalisis peranan suatu sektor ataupun pergeseran suatu sektor di daerah terhadap sektor yang sama dalam perekonomian nasional. Data yang sering dianalisis adalah data yang terkait kegiatan 
ekonomi ataupun ketenagakerjaan (Putra, 2011). SS membandingkan perbedaan laju pertumbuhan sektor (industri) di wilayah yang sempit disebut daerah dengan wilayah yang lebih luas disebut nasional (Tarigan, 2005).

Suatu daerah yang memiliki banyak sektor yang tingkat pertumbuhannya lamban, maka sektor tersebut pertumbuhannya secara nasional juga akan lamban. Hal ini terjadi karena daerahdaerah lain tumbuh lebih cepat (Putra, 2011). Analisis SS memiliki tiga komponen (Tarigan, 2005), yaitu: (a). National Share; (b). Proportional Shift; dan (c). Differential Shift.

a) National share untuk mengetahui pergeseran struktur perekonomian suatu daerah yang dipengaruhi oleh pergeseran perekonomian nasional.

b) Proportional shift adalah pertumbuhan nilai tambah bruto suatu sektor i dibandingkan total sektor di tingkat nasional.

c) Differential shift atau competitive position adalah perbedaan pertumbuhan perekonomian suatu daerah dengan nilai tambah bruto sektor yang sama di tingkat nasional.

Kecamatan Cipatujah didominasi oleh sektor pertanian dalam arti luas, namun gambaran tersebut belum dapat menjelaskan dan mengarahkan secara lebih spesifik komoditas unggulan pertanian yang ada saat ini. Tujuan penelitian ini yaitu untuk mengetahui, (1) Nilai LQ pertanian tanaman pangan Kecamatan Cipatujah berdasarkan luas panen, (2) Nilai LQ pertanian tanaman pangan Kecamatan Cipatujah berdasarkan nilai produksi, (3) Komoditi unggulan yang memiliki nilai keunggulan kompetitif berdasarkan luas panen, (4) Komoditi unggulan yang memiliki nilai keunggulan kompetitif berdasarkan nilai produksi, dan (5) Komoditas unggulan utama dan terpilih sesuai analisis LQ dan SS berdasarkan luas panen dan nilai produksi.

\section{METODE PENELITIAN}

Penelitian ini merupakan penelitian deskriptif kualitatif. Metode deskriptif merupakan sebuah metode penelitian yaitu dengan cara mengumpulkan data-data yang sesuai dengan yang sebenarnya kemudian data tersebut disusun, diolah dan kemudian dianalisis untuk dapat memberikan gambaran mengenai masalah yang ada di daerah tersebut (Sugiyono, 2008). Penelitian ini menggambarkan komoditi unggulan tanaman pangan di Kecamatan Cipatujah dengan menganalisis data sekunder yang kemudian diambil kesimpulan. 
Variabel yang digunakan dalam penelitian ini dioperasionalisasikan sebagai berikut:

1. Komoditi tanaman pangan adalah segala sesuatu jenis tanaman yang di dalamnya mengandung karbohidrat sebagai sumber energi bagi manusia.adapun tanaman pangan itu sendiri meliputi:serealia, biji-bijian dan umbi-umbian.

2. Analisis LQ adalah suatu perbandingan tentang besarnya peranan suatu sektor/industri di suatu daerah terhadap peranan suatu sektor/industri.

3. Analisis SS adalah analisis yang dilakukan untuk mengetahui keunggulan kompetitif suatu komoditi pertanian di suatu wilayah dalam cakupan wilayah agregat yang lebih luas berdasarkan kinerja sektor lokal di wilayah tersebut. Analisis SS terdiri atas tiga komponen, yaitu:

a) National share, menunjukan kontribusi pergeseran total seluiruh sektor di total wilayah agregat yang lebih luas.

b) Proportional shift, menunjukan pergeseran total sektor tertentu di wilayah agregat yang lebih luas.

c) Differential shift, menunjukan pergeseraan suatu sektor tertentu di suatu wilayah tertentu.
Data yang digunakan merupakan data sekunder yang diperoleh dari BPS Kabupaten Tasikmalaya berupa data luas panen dan produksi komoditas tanaman pangan di Kecamatan Cipatujah tahun 2010-2019.

\section{Analisis Location Quotient (LQ)}

Analisis LQ digunakan untuk menentukan komoditas sub-sektor tanaman pangan yang memiliki keunggulan komparatif, dengan kriteria LQ $>1$. Secara operasional, formulasi LQ dapat dirumuskan sebagai berikut (Hendayana, 2003):

$$
L Q=\frac{p i / p t}{P i / P t}
$$

Dimana:

pi $=$ luas areal panen komoditas $\mathrm{i}$ pada tingkat desa

$\mathrm{pt}=$ total luas areal panen semua komoditas pada tingkat desa

$\mathrm{Pi}=$ total luas areal panen komoditas $\mathrm{i}$ pada tingkat kecamatan

$\mathrm{Pt}=$ luas areal panen komoditas total pada tingkat kecamatan.

Hasil perhitungan LQ menghasilkan tiga (3) kriteria, yaitu:

a) LQ $>1$; artinya komoditas itu menjadi basis atau menjadi sumber pertumbuhan. Komoditas memiliki keunggulan komparatif, hasilnya tidak saja dapat memenuhi kebutuhan di wilayah bersangkutan akan tetapi juga dapat diekspor ke luar wilayah. 
b) $\mathrm{LQ}=1$; komoditas itu tergolong non basis, tidak memiliki keunggulan komparatif. Produksinya hanya cukup untuk memenuhi kebutuhan wilayah sendiri dan tidak mampu untuk diekspor.

c) LQ $<1$; komoditas ini juga termasuk non basis. Produksi komoditas di suatu wilayah sendiri sehingga perlu pasokan atau impor dari luar.

\section{Analisis Shift Share (SS)}

Analisis SS digunakan untuk menentukan komoditas sub-sektor tanaman pangan yang memiliki keunggulan kompetitif, dengan kriteria SS positif. Secara matematis, metode SS diformulasikan sebagai berikut (Rustiadi dkk, 2011):

$$
S S A=\left(\frac{X . .(t 1)}{X . .(t 0)}-1\right)+\left(\frac{X i(t 1)}{X i(t 0)}-\frac{X . .(t 1)}{X . .(t 0)}\right)+\left(\frac{X i j(t 1)}{X i j(t 0)}-\frac{X i(t 1)}{X i(t 0)}\right)
$$

Dimana:

$$
\begin{array}{ll}
\mathrm{a} & =\text { komponen regional share } \\
\mathrm{b} & =\text { komponen proportional shift } \\
\mathrm{c} & =\text { komponen differential shift } \\
\mathrm{X} . . & =\text { nilai total aktivitas dalam total } \\
& \text { wilayah } \\
\mathrm{Xi} & =\text { nilai total aktivitas tertentu dalam } \\
& \text { total wilayah } \\
\mathrm{Xij} & =\text { nilai aktivitas tertentu dalam unit } \\
& \text { wilayah tertentu } \\
\mathrm{t} 1 & =\text { titik tahun terakhir } \\
\mathrm{t} 0 & =\text { titik tahun awal }
\end{array}
$$

\section{HASIL DAN PEMBAHASAN}

Komoditas yang mempunyai keunggulan komparatif menunjukkan bahwa komoditas tersebut produksinya didominasi oleh dukungan sumber daya alam, dimana daerah lain tidak mampu untuk memproduksinya. Saptana (2008)

\begin{tabular}{|c|c|c|c|c|c|c|}
\hline No & Desa & $\begin{array}{c}\text { Padi } \\
\text { sawah }\end{array}$ & $\begin{array}{l}\text { Padi } \\
\text { Gogo }\end{array}$ & $\begin{array}{c}\text { Jagun } \\
\text { g }\end{array}$ & $\begin{array}{c}\text { Ubi } \\
\text { Kayu }\end{array}$ & $\begin{array}{l}\text { Kacang } \\
\text { Tanah }\end{array}$ \\
\hline 1 & Ciheras & 0,72 & 1,15 & 1,42 & 1,58 & 1,73 \\
\hline 2 & Cipatujah & 0,61 & 1,06 & 1,28 & 2,08 & 2,34 \\
\hline 3 & Sindangkerta & 1,05 & 0,83 & 0,73 & 1,13 & 1,23 \\
\hline 4 & $\begin{array}{l}\text { Cikawungadin } \\
\mathrm{g}\end{array}$ & 093 & 1,19 & 0,88 & 1,15 & 1,21 \\
\hline 5 & Bantarkalong & 1,25 & 0,58 & 0,46 & 0,86 & 0,93 \\
\hline 6 & Darawati & 1,19 & 0,70 & 0,00 & 0,89 & 1,02 \\
\hline 7 & Nagrog & 1,22 & 0,70 & 0,64 & 0,75 & 0,77 \\
\hline 8 & Pameutingan & 0,85 & 1,19 & 1,20 & 1,25 & 1,29 \\
\hline 9 & Tobongjaya & 1,24 & 0,53 & 0,41 & 0,95 & 1,05 \\
\hline 10 & Cipanas & 1,08 & 0,94 & 0,72 & 0,96 & 0,99 \\
\hline 11 & Kertasari & 1,21 & 0,74 & 0,60 & 0,77 & 0,79 \\
\hline 12 & Ciandum & 1,02 & 1,12 & 1,52 & 0,46 & 0,49 \\
\hline 13 & Nangelasari & 0,98 & 1,43 & 1,13 & 0,57 & 0,58 \\
\hline 14 & Padawaras & 0,95 & 1,30 & 1,36 & 0,67 & 0,39 \\
\hline 15 & Sukahurip & 0,86 & 1,28 & 1,64 & 0,93 & 0,25 \\
\hline
\end{tabular}
menyatakan bahwa konsep keunggulan komparatif adalah kelayakan ekonomi. Pengidentifikasian subsektor pertanian unggulan akan mempermudah dalam menentukan komoditas yang dikembangkan. Hal ini memerlukan analisis pada tiap subsektor di masingmasing wilayah sehingga pengembangan komoditi pada tiap wilayah dapat berjalan baik (Drianti dan Ardiyanto, 2016 dalam Isyanto dkk., 2019).

Hasil analisis LQ berdasarkan luas panen menunjukkan bahwa komoditas padi sawah memiliki keunggulan komparatif di 8 desa, padi gogo memiliki keunggulan komparatif di 8 desa, jagung memiliki keunggulan komparatif di 7 desa, kacang tanah memiliki keunggulan komparatif di 7 desa. Hal tersebut menunjukkan bahwa komoditas yang unggul di setiap desa tersebut merupakan komoditas basis yang 
dapat memenuhi kebutuhan pada daerah tersebut, bahkan dapat disuplai ke luar dari desa tersebut.

Komoditas padi sawah, padi gogo, jagung, ubi kayu, dan kacang tanah memiliki keunggulan komparatif di desa tertentu karena share luas panennya di tingkat desa lebih tinggi dibandingkan dengan di tingkat kecamatan, sehingga nilai LQ lebih besar dari 1 .

\begin{tabular}{|c|c|c|}
\hline \multicolumn{3}{|c|}{$\begin{array}{l}\text { Tabel 3. Komoditi Tanaman Pangan yang Memiliki } \\
\text { Keunggulan Komparatif di Kecamatan Cipatujah } \\
\text { Menurut Luas Panen }\end{array}$} \\
\hline No & Desa & Komoditas \\
\hline 1 & Ciheras & $\begin{array}{l}\text { Padi gogo, Jagung, Ubi Kayu, } \\
\text { Kacang tanah }\end{array}$ \\
\hline 2 & Cipatujah & $\begin{array}{l}\text { Padi gogo, Jagung, Ubi Kayu, } \\
\text { Kacang tanah }\end{array}$ \\
\hline 3 & Sindangkerta & $\begin{array}{l}\text { Padi sawah Ubi kayu, Kacang } \\
\text { tanah }\end{array}$ \\
\hline 4 & Cikawungading & $\begin{array}{l}\text { Padi gogo, Ubi kayu, Kacang } \\
\text { tanah }\end{array}$ \\
\hline 5 & Bantarkalong & Padi sawah \\
\hline 6 & Darawati & Padi sawah, Kacang tanah \\
\hline 7 & Nagrog & Padi sawah \\
\hline 8 & Pameutingan & $\begin{array}{l}\text { Padi gogo, Jagung, Ubi kayu, } \\
\text { Kacang tanah }\end{array}$ \\
\hline 9 & Tobongjaya & Padi sawah, Kacang tanah \\
\hline 10 & Cipanas & Padi sawah, \\
\hline 11 & Kertasari & Padi sawah, \\
\hline 12 & Ciandum & Padi sawah, Padi gogo, Jagung \\
\hline 13 & Nangelasari & Padi gogo, Jagung, \\
\hline 14 & Padawaras & Padi gogo, Jagung, \\
\hline 15 & Sukahurip & Padi gogo, Jagung, \\
\hline
\end{tabular}

Sumber: Hasil olah data sekunder, 2020

Tabel 3 menjelaskan bahwa secara wilayah, terdapat 3 desa yang memiliki komoditas paling banyak yang unggul secara komparatif menurut luas panen.

\begin{tabular}{clrccrr}
\multicolumn{6}{c}{ Tabel 4.Hasil Analisis LQ } & \multicolumn{7}{c}{ Menurut } & Nilai Produksi & \\
\hline \multirow{2}{*}{ No } & \multicolumn{1}{c}{ Desa } & $\begin{array}{c}\text { Padi } \\
\text { sawah }\end{array}$ & $\begin{array}{c}\text { Padi } \\
\text { Gogo }\end{array}$ & $\begin{array}{c}\text { Jagun } \\
\text { g }\end{array}$ & $\begin{array}{c}\text { Ubi } \\
\text { Kayu }\end{array}$ & $\begin{array}{c}\text { Kacang } \\
\text { Tanah }\end{array}$ \\
\hline 1 & Ciheras & 0,79 & 1,15 & 1,95 & 1,09 & 1,42 \\
2 & Cipatujah & 0,57 & 0,97 & 0,75 & 2,27 & 2,39 \\
3 & Sindangkerta & 1,10 & 0,70 & 0,48 & 1,15 & 1,09 \\
4 & Cikawungadin & 0,87 & 1,19 & 0,94 & 1,22 & 1,12 \\
5 & g & & & & & \\
5 & Bantarkalong & 1,35 & 0,51 & 0,18 & 0,73 & 0,56 \\
6 & Darawati & 1,14 & 0,98 & 0,30 & 0,91 & 0,77 \\
7 & Nagrog & 0,97 & 1,18 & 0,95 & 0,97 & 0,90 \\
8 & Pameutingan & 0,87 & 1,14 & 1,29 & 1,13 & 1,00 \\
9 & Tobongjaya & 1,18 & 0,52 & 0,05 & 1,24 & 0,98 \\
10 & Cipanas & 1,07 & 0,93 & 0,71 & 0,98 & 0,89 \\
11 & Kertasari & 1,14 & 0,79 & 0,67 & 0,91 & 0,80 \\
12 & Ciandum & 1,00 & 0,89 & 2,45 & 0,53 & 1,04 \\
13 & Nangelasari & 0,83 & 1,73 & 1,11 & 0,84 & 1,17 \\
14 & Padawaras & 1,11 & 1,18 & 1,11 & 0,51 & 0,60 \\
15 & Sukahurip & 0,78 & 1,46 & 2,08 & 0,84 & 0,63 \\
\hline
\end{tabular}

Sumber: Hasil olah data sekunder, 2020

Nilai LQ berdasarkan nilai produksi menunjukkan bahwa komoditas padi sawah memiliki keunggulan komparatif di 7 desa, padi gogo memiliki keunggulan komparatif di 7 desa, jagung memiliki keunggulan komparatif di 6 desa, ubi kayu memiliki keunggulan komparatif di 6 desa, kacang tanah memiliki keunggulan komparatif di 6 desa. Hal tersebut menunjukkan bahwa komoditas yang unggul di setiap desa tersebut merupakan komoditas basis yang dapat memenuhi kebutuhan pada daerah tersebut, bahkan dapat disuplai ke luar dari desa tersebut.

Tabel 5 menjelaskan bahwa secara wilayah, terdapat 2 desa yang memiliki komoditas paling banyak yang unggul secara kompetitif menurut nilai produksi.

\begin{tabular}{|c|c|c|}
\hline & $\begin{array}{l}\text { Komoditi Ta } \\
\text { Keunggulan K } \\
\text { Menurut Nilai I }\end{array}$ & $\begin{array}{l}\text { aman Pangan yang Memiliki } \\
\text { nparatif di Kecamatan Cipatujah } \\
\text { oduksi }\end{array}$ \\
\hline No & Desa & Komoditas \\
\hline 1 & Ciheras & $\begin{array}{l}\text { Padi gogo, Jagung, Ubi Kayu, } \\
\text { Kacang tanah }\end{array}$ \\
\hline 2 & Cipatujah & Ubi Kayu, Kacang tanah \\
\hline 3 & Sindangkerta & $\begin{array}{l}\text { Padi sawah, Ubi kayu, Kacang } \\
\text { tanah }\end{array}$ \\
\hline 4 & Cikawungading & $\begin{array}{l}\text { Padi gogo, Ubi kayu, Kacang } \\
\text { tanah }\end{array}$ \\
\hline 5 & Bantarkalong & Padi sawah \\
\hline 6 & Darawati & Padi sawah \\
\hline 7 & Nagrog & Padi gogo \\
\hline 8 & Pameutingan & $\begin{array}{l}\text { Padi gogo, Jagung, Ubi kayu, } \\
\text { Kacang tanah }\end{array}$ \\
\hline 9 & Tobongjaya & Padi sawah, Ubi kayu \\
\hline 10 & Cipanas & Padi sawah \\
\hline 11 & Kertasari & Padi sawah \\
\hline 12 & Ciandum & Jagung, Kacang tanah \\
\hline 13 & Nangelasari & Padi gogo, Jagung, Kacang tanah \\
\hline 14 & Padawaras & Padi sawah, Padi gogo, Jagung, \\
\hline 15 & Sukahurip & Padi gogo, Jagung, \\
\hline
\end{tabular}




\begin{tabular}{ccc}
14 & Padawaras & Padi sawah \\
15 & Sukahurip & - \\
\hline Sumber: Hasil olah data sekunder, 2020
\end{tabular}

\section{Analisis Shift Share (SS)}

Komoditas tanaman pangan yang memiliki keunggulan kompetitif yang ditentukan berdasarkan nilai SS positif. Komoditas tanaman pangan yang mempunyai keunggulan kompetitif artinya produksi komoditas tersebut dilakukan dengan cara yang efektif dan efisien. Sehingga mempunyai daya saing dari aspek kuantitas, kualitas, kontinuitas, dan harga

\begin{tabular}{clrrrrr}
\multicolumn{6}{c}{ Tabel 6. Hasil Analisis Shift } & \multicolumn{6}{c}{ Share Menurut Luas Panen } \\
\hline No & \multicolumn{1}{c}{ Desa } & $\begin{array}{c}\text { Padi } \\
\text { sawah }\end{array}$ & $\begin{array}{c}\text { Padi } \\
\text { Gogo }\end{array}$ & Jagung & $\begin{array}{c}\text { Ubi } \\
\text { Kayu }\end{array}$ & $\begin{array}{c}\text { Kacang } \\
\text { Tanah }\end{array}$ \\
\hline 1 & Ciheras & 1,94 & $-0,29$ & $-0,67$ & $-0,88$ & $-0,93$ \\
2 & Cipatujah & 0,08 & $-0,78$ & $-0,88$ & $-0,90$ & $-0,93$ \\
3 & Sindangkerta & 1,36 & $-0,25$ & $-0,79$ & $-0,82$ & $-0,93$ \\
4 & Cikawungadin & 1,16 & 0,50 & $-0,77$ & $-0,77$ & $-0,91$ \\
& g & & & & & \\
5 & Bantarkalong & 0,83 & $-0,20$ & $-0,82$ & $-0,65$ & $-0,82$ \\
6 & Darawati & 0,25 & 0,04 & $-0,76$ & $-0,62$ & $-0,81$ \\
7 & Nagrog & 0,75 & 0,41 & $-0,58$ & $-0,67$ & $-0,90$ \\
8 & Pameutingan & 0,35 & 0,42 & $-0,22$ & $-0,72$ & $-0,92$ \\
9 & Tobongjaya & $-0,18$ & $-0,44$ & $-1,00$ & $-0,57$ & $-0,85$ \\
10 & Cipanas & $-0,28$ & 0,69 & $-0,52$ & $-0,56$ & $-0,81$ \\
11 & Kertasari & $-0,07$ & 0,35 & $-0,47$ & $-0,75$ & $-0,93$ \\
12 & Ciandum & 0,09 & $-0,82$ & $-0,81$ & $-0,48$ & $-0,74$ \\
13 & Nangelasari & $-0,39$ & $-0,48$ & $-0,91$ & $-0,47$ & $-0,68$ \\
14 & Padawaras & 4,74 & $-0,68$ & $-0,91$ & $-0,55$ & $-0,75$ \\
15 & Sukahurip & $-0,22$ & $-0,61$ & $-0,88$ & $-0,67$ & $-0,43$ \\
\hline \multicolumn{5}{l}{ Sumber: Hasil olah data sekunder, 2020 } & &
\end{tabular}

Hasil analisis SS berdasarkan luas panen diketahui bahwa komoditas padi sawah memiliki keunggulan kompetitif di 10 desa dan padi gogo memiliki keunggulan kompetitif di 6 desa.

Tabel 7.Komoditi Tanaman Pangan yang Memiliki Keunggulan Kompetitif di Kecamatan Cipatujah Menurut Luas Panen

\begin{tabular}{cll}
\multicolumn{3}{c}{ Menurut Luas Panen } \\
\hline No & \multicolumn{1}{c}{ Desa } & \multicolumn{1}{c}{ Komoditas } \\
\hline 1 & Ciheras & Padi sawah \\
2 & Cipatujah & Padi sawah \\
3 & Sindangkerta & Padi sawah \\
4 & Cikawungading & Padi sawah, Padi gogo \\
5 & Bantarkalong & Padi sawah \\
6 & Darawati & Padi sawah, Padi gogo \\
7 & Nagrog & Padi sawah, Padi gogo \\
8 & Pameutingan & Padi sawah, Padi gogo \\
9 & Tobongjaya & - \\
10 & Cipanas & Padi gogo \\
11 & Kertasari & Padi gogo \\
12 & Ciandum & Padi sawah \\
13 & Nangelasari & -
\end{tabular}

Tabel 7 menjelaskan bahwa secara wilayah, terdapat 4 desa yang memiliki komoditas paling banyak yang unggul secara kompetitif menurut luas panen.

Tabel 8. Hasil Analisis Shift Share Menurut Nilai Produksi

\begin{tabular}{llrrrrr}
\hline No & \multicolumn{1}{c}{ Desa } & $\begin{array}{c}\text { Padi } \\
\text { sawah }\end{array}$ & $\begin{array}{c}\text { Padi } \\
\text { Gogo }\end{array}$ & Jagung & $\begin{array}{c}\text { Ubi } \\
\text { Kayu }\end{array}$ & $\begin{array}{c}\text { Kacang } \\
\text { Tanah }\end{array}$ \\
\hline 1 & Ciheras & 3,45 & 0,32 & 3,54 & $-0,77$ & $-0,92$ \\
2 & Cipatujah & 0,66 & $-0,60$ & $-0,83$ & $-0,88$ & $-0,92$ \\
3 & Sindangkerta & 2,44 & 0,41 & $-0,71$ & $-0,78$ & $-0,92$ \\
4 & Cikawungadin & 2,24 & 1,81 & $-0,69$ & $-0,71$ & $-0,90$ \\
& g & & & & & \\
5 & Bantarkalong & 1,77 & 0,48 & $-0,74$ & $-0,58$ & $-0,80$ \\
6 & Darawati & 0,89 & 0,99 & $-0,66$ & $-0,55$ & $-0,79$ \\
7 & Nagrog & 1,57 & 1,60 & $-0,43$ & $-0,61$ & $-0,89$ \\
8 & Pameutingan & 1,02 & 1,72 & 0,10 & $-0,67$ & $-0,90$ \\
9 & Tobongjaya & 0,19 & 0,02 & $-1,00$ & $-0,49$ & $-0,83$ \\
10 & Cipanas & 0,04 & 2,11 & $-0,32$ & $-0,49$ & $-0,78$ \\
11 & Kertasari & 0,29 & 1,44 & $-0,24$ & $-0,70$ & $-0,92$ \\
12 & Ciandum & 0,80 & $-0,61$ & $-0,74$ & 1,26 & $-0,95$ \\
13 & Nangelasari & $-0,16$ & $-0,53$ & $-0,86$ & 1,36 & $-0,94$ \\
14 & Padawaras & 7,89 & $-0,72$ & $-0,85$ & 0,93 & $-0,96$ \\
15 & Sukahurip & $-0,03$ & $-0,65$ & $-0,84$ & 0,48 & $-0,90$ \\
\hline Sumber: Hasil olah data sekunder, 2020
\end{tabular}

Hasil analisis SS menurut nilai produksi diketahui bahwa komoditas padi sawah memiliki keunggulan kompetitif di 13 desa, padi gogo memiliki keunggulan kompetitif di 10 desa, jagung memiliki keunggulan kompetitif di 2 desa dan ubi kayu memiliki keunggulan kompetitif di 4 desa.

Tabel 9.Komoditi Tanaman Pangan yang Memiliki Keunggulan Kompetitif di Kecamatan Cipatujah Menurut Nilai Produksi

\begin{tabular}{cll}
\hline No & \multicolumn{1}{c}{ Desa } & \multicolumn{1}{c}{ Komoditas } \\
\hline 1 & Ciheras & Padi sawah, Padi gogo, Jagung \\
2 & Cipatujah & Padi sawah \\
3 & Sindangkerta & Padi sawah, Padi gogo \\
4 & Cikawungading & Padi sawah, Padi gogo, \\
5 & Bantarkalong & Padi sawah, Padi gogo \\
6 & Darawati & Padi sawah, Padi gogo, \\
7 & Nagrog & Padi sawah, Padi gogo, \\
8 & Pameutingan & Padi sawah, Padi gogo, Jagung \\
9 & Tobongjaya & Padi sawah \\
10 & Cipanas & Padi gogo, \\
11 & Kertasari & Padi gogo, \\
12 & Ciandum & Padi sawah, Ubi kayu \\
13 & Nangelasari & Ubi kayu \\
14 & Padawaras & Padi sawah, Ubi kayu
\end{tabular}


15 Sukahurip Ubi kayu

Sumber: Hasil olah data sekunder, 2020

Tabel 9 menjelaskan bahwa secara wilayah, terdapat 2 desa yang memiliki komoditas paling banyak yang unggul secara kompetitif menurut nilai produksi.

Komoditas yang memiliki keunggulan kompetitif di desa tertentu mengalami pertumbuhan sehingga mempunyai nilai yang positif. Sebaliknya untuk komoditas yang tidak memiliki keunggulan kompetitif tidak terjadi pertumbuhan sehingga bernilai negatif. Komoditas yang mempunyai keunggulan kompetitif didapat dari kumulatif regional share, propotional shift, dan differential shift bernilai positif.

\section{Keunggulan Komparatif dan Kompetitif}

Komoditas yang memiliki keunggulan komparatif dan kompetitif diperoleh dari nilai LQ > 1 dan SS yang bernilai positif. Hasil analisis diketahui komoditas padi sawah memiliki keunggulan komparatif dan kompetitif di 5 desa, dan padi gogo memiliki keunggulan di 2 desa.

\begin{tabular}{cll}
\multicolumn{2}{c}{ Tabel 10. Komoditi } & $\begin{array}{c}\text { Tanaman Pangan } \\
\text { Keunggulan } \\
\text { Kecamatan Cipatujah Menurut Luas Panen }\end{array}$ \\
\hline \multicolumn{1}{c}{ Desa } & \multicolumn{1}{c}{ Kemiliki } \\
Nomoditas \\
\hline 1 & Ciheras & - \\
2 & Cipatujah & - \\
3 & Sindangkerta & Padi sawah \\
4 & Cikawungading & Padi gogo \\
5 & Bantarkalong & Padi sawah \\
6 & Darawati & Padi sawah \\
7 & Nagrog & Padi sawah \\
8 & Pameutingan & Padi gogo \\
9 & Tobongjaya & - \\
10 & Cipanas & -
\end{tabular}

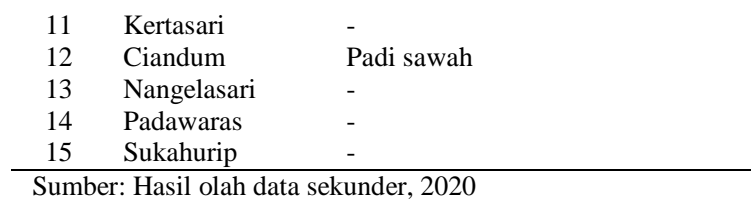

Komoditas yang memiliki keunggulan komparatif dan kompetitif menurut luas panen yaitu, komoditas padi sawah yang memiliki keunggulan di 5 desa, padi gogo yang memiliki keunggulan di 4 desa, dan jagung yang memiliki keunggulan di 2 desa.

\begin{tabular}{cll} 
Tabel 11. Komoditi & \multicolumn{1}{c}{ Tanaman Pangan yang Memiliki } \\
\multicolumn{4}{c}{$\begin{array}{c}\text { Keunggulan } \\
\text { Kecamatan Cipatujah Menurut Nilai Produksi }\end{array}$} \\
\hline \multicolumn{1}{c}{ Desa } \\
\hline No & \multicolumn{1}{c}{ Komoditas } \\
\hline 1 & Ciheras & Padi gogo, Jagung \\
3 & Cipatujah & - \\
4 & Sindangkerta & Padi sawah \\
5 & Cikawungading & Padi gogo \\
6 & Dantarkalong & Padi sawah \\
7 & Nagrog & Padi sawah \\
8 & Pameutingan & Padi gogo \\
9 & Tobongjaya & Padi gogo, Jagung \\
10 & Cipanas & - \\
11 & Kertasari & - \\
12 & Ciandum & - \\
13 & Nangelasari & - \\
14 & Padawaras & Padi sawah \\
15 & Sukahurip & - \\
\hline Sumber: Hasil olah data sekunder, 2020
\end{tabular}




\section{KESIMPULAN DAN SARAN}

\section{Kesimpulan}

Komoditi tanaman pangan yang menjadi unggulan berdasarkan luas panen yaitu padi sawah, padi gogo, jagung, ubi kayu, dan kacang tanah, sedangkan berdasarkan nilai produksi yaitu padi sawah, padi gogo, jagung, ubi kayu, dan kacang tanah. Komoditi tanaman pangan yang memiliki keunggulan kompetitif berdasarkan luas panen yaitu, padi sawah dan padi gogo, sedangkan berdasarkan nilai produksi yaitu, padi sawah, padi gogo, jagung dan ubi kayu. Kemudian untuk komoditi tanaman pangan yang memiliki keunggulan komparatif dan kompetitif berdasarkan luas panen yaitu, padi sawah dan padi gogo, sedangkan berdasarkan nilai produksi yaitu padi sawah, padi gogo, dan jagung.

\section{Saran}

Komoditi tanaman pangan yang mempunyai nilai LQ $<1$ harus diupayakan untuk dilakukan peningkatan luas panen serta peningkatan produktivitas dengan memaksimalkan penggunaan teknologi dan input produksi yang digunakan. Upaya peningkatan produktivitas memerlukan dukungan dari pemerintah kepada petani dalam bentuk kemudahan mendapatkan sarana produksi usahatani serta peningkatan prasarana dan sarana pertanian terutama irigasi dan alat mesin pertanian. Selain itu, harus ada upaya untuk mendorong pertumbuhan komoditi tanaman pangan lain yang dapat dijadikan sebagai komoditas unggulan yang sesuai dengan potensi wilayahnya.

\section{DAFTAR PUSTAKA}

Badan Pusat Statsitik. 2019. Kabupaten Tasikmalaya dalam angka 2019. Kabupaten Tasikmalaya: Badan Pusat Statsistik.

Hendayana, R. 2003. Aplikasi Metode Location Quotient (LQ) Dalam Penentuan Komoditi Unggulan Nasional. Jurnal Informatika Pertanian 12:658-675.

Isyanto, A.Y., Sudrajat, Yusuf, M.N., Novianty, A., Andrie, B.M., Priantika, W., Harli, N, dan Aziz, S. 2019. Komoditas Potensial Tanaman Palawija Di Kabupaten Blora Provinsi Jawa Tengah. Mimbar Agribisnis: Jurnal Pemikiran Masyarakat Ilmiah Berwawasan Agribisnis, 5(2): 368-378.

Putra, N. 2011. Research and Development Penelitian dan Pengembangan: Suatu Pengantar. Jakarta: Rajagrafindo Persada.

Saptana. 2008. Keunggulan KomparatifKompetitif dan Strategi Kemitraan. Jurnal Soca (Socio-Economic of Agriculturre and Agribusiness), 8(2) :10-26.

Sugiyono. 2008. Metode Penelitian Kuantitatif Kualitatif dan $R \& D$. Bandung: Alfabeta.

Tarigan, R. 2005. Ekonomi Regional. Teori dan Aplikasi. Bumi Aksara. Jakarta. 